inOedia $\quad \begin{aligned} & \text { InMedia } \\ & \text { The French Journal of Media Studies }\end{aligned}$

3 | 2013

Cinema and Marketing

\title{
Cinema and Marketing: When Cultural Demands Meet Industrial Practices
}

Nathalie Dupont and Joël Augros

\section{(2) OpenEdition \\ 1 Journals}

Electronic version

URL: https://journals.openedition.org/inmedia/625

DOI: 10.4000/inmedia.625

ISSN: 2259-4728

Publisher

Center for Research on the English-Speaking World (CREW)

Electronic reference

Nathalie Dupont and Joël Augros, "Cinema and Marketing: When Cultural Demands Meet Industrial Practices", InMedia [Online], 3 | 2013, Online since 22 April 2013, connection on 21 September 2021. URL: http://journals.openedition.org/inmedia/625 ; DOI: https://doi.org/10.4000/inmedia.625

This text was automatically generated on 21 September 2021

(C) InMedia 


\title{
Cinema and Marketing: When Cultural Demands Meet Industrial Practices
}

\author{
Nathalie Dupont and Joël Augros
}

\section{EDITOR'S NOTE}

This dossier was followed for InMedia by Divina Frau-Meigs and Charlotte Gould.

1 With the advent of the modern consumer society, being able to sell mass-produced objects on a large scale became part and parcel of the modern way to do business. Consequently, the art of marketing, of creating advertisements able to entice people to buy precise items, was further developed. The cinema industry that grew in the $1910 \mathrm{~s}$ and 1920s also resorted to marketing to sell its films to the largest possible audience. As production costs started increasing, ${ }^{1}$ marketing became a key component of film releases, and it has never stopped since then. For example, at the turn of the $21^{\text {st }}$ century, the Motion Picture Association of America (MPAA) member companies spent an average of $\$ 47.7$ million to produce a film and $\$ 31$ million to market it, and in 2010, Hollywood studios spent a total of $\$ 3.6$ billion to advertise their motion pictures. ${ }^{2}$ Consequently, there has been a growing interest in the subject of cinema and marketing, not only from trade publications but also from the academic world, whether it be in Europe or in the United States.

2 According to John Caldwell, quoted by Daniel Steinhart, marketing can be "viewed as a quintessential form of industrial self-representation." ${ }^{3}$ Film marketing thus has specific characteristics linked to the product it is supposed to sell. But films are not the usual type of mass-produced items, they are not the result of carefully planned gestures on an assembly line. Needless to say, a lot of technical expertise is involved in the development and the making of motion pictures, but each film is unique and cannot really be reproduced - even if Hollywood now and then releases remakes or sequels 
that aim at copying, for better or for worse, what made a motion picture successful. Films also reflect their era, and are ultimately experienced in the darkness of a movie theatre by different people who have come to share the same experience for two hours or so. Films can even become symbolic, social or popular events, as was the case for example with Star Wars (George Lucas, 1977).

Cinema is thus a complex cultural industry, and the challenge facing marketers when it comes to films is quite daunting. People may need to go to the cinema now and then to have a good time or to try to forget about their worries, but the average cinemagoer rarely needs to see a particular film. Therefore, marketers have to create a whole experience, the urge to see a product whose fleeting value-or lack of it-is only known after it has been watched. Marketers have to deliver to the right crowd in the right way and in a short time span what is both a commercial product and the result of a historical, social and national context, while "positioning [it] in relation to its competitors," as noted by Peter Krämer. The challenge is even more daunting for independently-produced films that, contrary to many studio blockbusters, are usually unknown right to the time of their release.

This situation leads to specific problems calling for specific answers. In the field of film studies, research linked to film marketing falls into two categories. On the one hand, there are the numerous 'how to ...' handbooks and studies focusing on one or several motion pictures. ${ }^{4}$ On the other hand, there are studies using an ideological approach and presenting marketing as a tool Hollywood uses to monitor and control its audiences, ${ }^{5}$ either to dazzle them or to accentuate Hollywood's domination of world cinema through tasteless American behemoths at the box office. The research group on Cinéma, Economie \& Sociétés Anglophones-Cinema, Economy in English-Speaking Countries (CinEcoSA) ${ }^{6}$ has tried to go beyond this dual approach. ${ }^{7}$ Marketing relies on both economics and culture, and as a result requires to explore the questions of identity, which are connected to a film's development as well as its advertising campaigns. But the issues of identities have to be associated with marketing practices in a globalized economy. Consequently, this fact also requires to compare marketing techniques used in the English-speaking film industries with practices from other cultural areas. The following themed section is therefore inspired by this approach and features original contributions by French and foreign scholars in the field of cinema.

5 Sheldon Hall's "Jerry Pickman: "The Picture Worked" Excerpts from the reminiscences of a Hollywood publicist" is a primary source that gives us a unique insider look into the business of marketing and distributing films in America. While mentioning classics like The Greatest Show on Earth (Cecil B. DeMille, 1952), Shane (George Stevens, 1953) or Psycho (Alfred Hitchcock, 1960), and famous names like Adolph Zukor or Alfred Hitchcock, this firsthand and precious testimony puts the human aspect of marketing to the forefront. It reminds us that advertising films has its uncertainties, but is also a human endeavour involving individuals like Jerry Pickman, whose dedication to their task can even transform an average film into something more than what it was meant to be. Last but not least, this unique look into the marketing business also shows how cinema marketing has evolved to reach an industrial level at the beginning of the 1980s, when "now you sell pictures like hot dogs-it's the same for everybody."

“ 'To prevent the present heat from dissipating': Stanley Kubrick and the Marketing of Dr. Strangelove" (1964) switches to the director's point of view. Marketing interests can sometimes converge or be different when it comes to film production or distribution 
companies and artists, and in "The Marketing of Dr. Strangelove," Peter Krämer depicts how a director involves himself in the marketing of his films. Stanley Kubrick is a famous artist who never balked at promoting his own motion pictures. Making extensive use of the Stanley Kubrick Archive at the University of the Arts London, the article describes how, from a very early stage, Stanley Kubrick got involved in the American marketing of Dr. Strangelove, up to the point of taking great care to neutralize any possible competitor. The article also underlines the fact that during the production and the first promotional campaign of Dr. Strangelove, the famous director was very gifted for his self-promotion, even if the marketing material later used for the second promotional campaign and the release of the film rather focused on the usual topics of "stars, comedy and sex."

7 Marketing films is also about profits, and this means taking specific audiences into account when dealing with a film genre. In "Targeting American Women: Movie Marketing, Genre History, and the Hollywood Women-in-Danger Film," Richard Nowell deals with women-in-danger films and their potential female audience. Spanning nearly a decade of the genre at a time when more women were breaking through the glass ceiling in America, "Targeting American Women" first centres on the ad campaigns for sensationally promoted exploitation fare at the end of the 1970s. Richard Nowell then goes on to analyze how Hollywood distributors, informed by those previous campaigns, carefully handled the marketing of the women-in-danger films released at the beginning of the 1980s. He argues that contrary to some studies that denounced women-in-danger films as "the greatest misogynist trend in American film history," the marketing analysis of those films shows that studios and distributors precisely wanted to avoid such potentially damaging accusations of misogyny. Hollywood's goal was to attract the adult female audience in a way that was later to shape the marketing campaigns of films targeting a similar audience.

"Marketing films to the American conservative Christians: the case of The Chronicles of Narnia" also deals with the subject of specific marketing, this time with a religious niche slant. The relationship between Hollywood and conservative religious groups has always been difficult, but Nathalie Dupont illustrates that now and then, the time is ripe for some kind of collaboration. Using the example of The Chronicles of Narnia, her article first describes the reasons that enticed Hollywood to target the American conservative Christians. It then goes on to describe the way Hollywood handled The Chronicles' Christian niche marketing and how it particularly targeted the Evangelicals. But the article also shows that Hollywood walked that path very cautiously, in what can only be a limited marketing collaboration solely destined to the American market.

9 The last section of this issue focuses on marketing films abroad. The foreign market was rapidly important for Hollywood, and in " 'Paris...As You've Never Seen It Before!!!': The Promotion of Hollywood Foreign Productions in the Postwar Era," Daniel Steinhart shows how authentic locations were used to promote postwar films on both the American and foreign markets. As the Hollywood industry was changing in the 1950s, shooting abroad became a way to distinguish films from television fare, and to lure audiences back into movie theatres. "Paris...As You've Never Seen It Before!!!" reflects these changes and thus sheds light on the self-image the American film industry was manufacturing at the time, for example in the way Hollywood publicists carefully brought to the fore authentic locations in the American and foreign press-and then in cinema lobbies-during all the development stages of a film. 

international distribution and marketing of a film can influence a project right from its inception. By pointing to various narrative elements, the article underlines how the Hollywood-Hong Kong co-production Enter the Dragon was designed to please both Asian and Western audiences, while launching the career of Bruce Lee in the United States. These elements were then used in the marketing of the film, as the latter was adapted to suit the tastes of local moviegoers. Consequently, elements linked to martial arts, the James Bond franchise, serial movies or comic books were more or less highlighted in the customized local marketing of the film. Finally, "The multiple facets of Enter the Dragon" also underlines that motion pictures can be a reflection of their time, as is made clear by the American marketing of the film. It was indeed clearly rooted in the political climate of the Cold War, consequently giving Enter the Dragon a dimension its Asian marketing clearly ignored.

11 Finally, “Woody Allen's French Marketing: 'Everyone Says Je l'aime,' or do they?" focuses on a specific aspect of marketing films abroad, i.e. the title and the poster that embody one of the first contacts audiences have with films. Frédérique Brisset compares the American and French posters for Woody Allen's films, their layout as well as their titles and their use of the para-text. She also shows how assumptions about French-speaking audiences may condition marketing strategies of the "Woody Allen brand" on the French market.

Spanning different eras, subjects and markets, the featured articles thus shed a new light on marketing and cinema. This relationship is an old and ongoing one that pertains to every type of motion pictures, whether studio or independent ones. These articles show that the relationship between marketing and cinema does not represent a by-product or an after-thought of the movie industry, but is truly part and parcel of film production and the experience of cinema-going.

\section{BIBLIOGRAPHY}

Austin Thomas. Hollywood, Hype, and Audiences: Selling and Watching Popular Film in the 1990s. Manchester and New York: Manchester University Press, 2002.

Calvo Herrera, Concepcion. Distribución y lanzamiento de una película. Alcalá : Grupo Editorial y Distribuidores de Libros, 2008.

Crafton, Donald. The Talkies: American Cinema's Transition to Sound (History of the American Cinema, vol. 4). Los Angeles: University of California Press, 2001.

Drake, Philip. "Distribution and Marketing in Contemporary Hollywood," in Wasko Janet and McDonald, Paul (eds), The Contemporary Hollywood Film Industry. Malden (MA) and Oxford: Blackwell, 2008.

Durie, John, Pham, Annika and Watson, Neil. Marketing and Selling Your Films around the World. Los Angeles: Silman-James Press, 2000.

InMedia, 3 | 2013 
Hayes, Dade and Bing, Jonathan. Open Wide. New York: Miramax books/Hyperion, 2004.

Kerrigan, Finola. Film Marketing. Oxford: Butterworth-Heinemann, 2010.

Laurichesse, Hélène. Quel marketing pour le cinéma ? Paris: CNRS Editions, 2006.

Lukk, Tiiu. Movie Marketing: Opening the Picture and Giving it Legs. Los Angeles: Silman-James Press, 1997.

Marich, Robert. Marketing to Moviegoers: A Handbook of Strategies Used by Major Studios and Independents. Boston: Focal Press, 2005.

Miller, Toby et al.. Global Hollywood. London: BFI Publishing, 2001.

Schatz, Thomas. Boom and Bust: American Cinema in the 1940s. (History of the American Cinema, vol. 6). Los Angeles: University of California Press, 1999.

Wyatt, Justin. High Concept: Movies and Marketing in Hollywood. Austin: University of Texas Press, 1994.

\section{NOTES}

1. For example with the arrival of sound in 1927, when The Jazz Singer (Alan Crosland) was one the films revealing the possibilities of the talking pictures.

2. Motion Picture Association of America, U.S. Entertainment Industry: 2002 MPA Market Statistics, http://www.mpaa.org <accessed May 8, 2003> and Robert Marich, "Research study details ad spend allocation," Variety, August 13, 2011. http://www.variety.com <accessed March 21, 2013>.

3. John Thornton Caldwell, Production Culture: Industrial Reflexivity and Critical Practice in Film and Television (Durham: Duke University Press, 2008), 274.

4. See for example Tiiu Lukk, Movie Marketing (Los Angeles: Silman-James Press, 1997), Dade Hayes and Jonathan Bing, Open Wide (New York: Miramax books/Hyperion, 2004) or Robert Marich, Marketing to Moviegoers: A Handbook of Strategies Used by Major Studios and Independents (Boston: Focal Press, 2005).

5. See for example Toby Miller et al., Global Hollywood (London: BFI Publishing, 2001).

6. CinEcoSA brings together academics working on the cinema and television industries of English-speaking countries. Their research focuses on American-English studies with an economic slant. http://www.cinecosa.com <accessed March 14, 2013>.

7. http://www.cinecosa.com/pages/Colloque_2010_Programme_et_photos-2792379.html <accessed March 14, 2013> et http://www.cinecosa.com/pages/ Journee_detude_2011_Programme-5913295.html <accessed March 14, 2013>.

\section{AUTHORS}

\section{NATHALIE DUPONT}

Nathalie Dupont is an Associate Professor in American studies at ULCO (Université du Littoral \& de la Côte d'Opale). She has published several articles on the American film industry. Her research interests also include how Hollywood films reflect the American society. She is a co- 
founder of research group CinEcoSA (http://www.cinecosa.com). She is currently writing a book on Walden Media.

\section{JOËL AUGROS}

Joël Augros is a Senior Lecturer at the Film Department of the Université Paris 8-Vincennes in Saint-Denis. After completing a PhD in Economics on the multimedia development of the international film industry, he continued his research on the economic aspects of Hollywood film and the French cinema. In the past years, he has been developing a comparative approach to the different film businesses across the world. 